Aleš GOLJA

Mitja BRILLY

\title{
Urejanje podeželskega prostora za rekreacijske namene na primeru zgornjega povodja reke Soče
}

\section{Planning countryside space for recreational purposes: the case of the upper water basin of the River Soča}

\begin{abstract}
Članek se na primeru zgornjega povodja reke Soče ukvarja s problematiko uporabe naravnih vrednot v turistične in rekreacijske namene. Predlagamo model ureditve rekreacijske rabe odseka reke Soče, izdelavo predloga formalnopravne ureditve upravljanja obravnavanega prostora in izdelavo režima upravljanja odseka reke Soče v rekreacijske namene, za kar smo izbrali najbolj obremenjeno območje povodja Soče v poletnih mesecih, to je devetkilometrski odsek Log ČezsoškiTrnovo ob Soči, in poskušali izdelati realen predlog trženja, predlog kontrole in predlog prostorske ureditve za zmanjšanje negativnih vplivov na okolje. Izbrana metodologija združuje znanje in prakse različnih strok, saj je treba tako kompleksno problematiko reševati v interdisciplinarni povezavi ekspertnih spoznanj. Naše glavno teoretsko izhodišče je bilo varstvo okolja, katerega cilj je varovati prostor kot vrednoto vsepovsod in $v$ vseh njenih pojavnih oblikah. Namen varstva okolja je spodbujanje in usmerjanje takšnega družbenega razvoja, ki omogoča dolgoročne razmere za človekovo zdravje, počutje in kakovost njegovega življenja ter ohranjanje biotske raznovrstnosti. Na izbranem območju lahko povežemo prostor z vsemi njegovimi sestavinami in značilnostmi, športno rekreacijo in turizem ter dosežemo kakovostno življenje avtohtonega prebivalstva, dobro počutje gostov, varovanje naravnega okolja, omogočanje gospodarskega razvoja, ustvarjanja delovnih mest in dohodka.
\end{abstract}

KLJUČNE BESEDE: varstvo okolja, rekreacija, turizem, reka Soča, Zgornje Posočje, krajinski park.

\section{Uvod}

V Evropi in po svetu je preživljanje prostega časa $\mathrm{v}$ naravnem okolju po gospodarski plati tako imenovana dodana vrednost podeželskega gospodarstva, zato so med glavnimi izzivi varstva okolja okoljsko načrtovanje in upravljanje podeželskega turizma, rekreacije, da bi ugotovili nosilno zmogljivost naravno občutljivega območja in koliko je turistični
Based on the upper Soča River basin, the article deals with the problem of exploitation of valuable natural features for tourist and recreational purposes. The goal was to propose a model of recreational use of a selected section of the Soča River, to put forward a proposal of legal framework for managing the selected area and work out a management plan for recreational purposes; thus the most burdened area of the Soča River during summer months was chosen, i.e. a $9 \mathrm{~km}$ reach of the Soča (between Log Čezsoški and Trnovo ob Soči), and accordingly a feasible marketing proposal, control proposal and spatial planning proposal were given in order to reduce the negative effects on the environment. The chosen methodology combines knowledge and practice from different fields, having in mind that this kind of problem solving should be carried out in an interdisciplinary connection of expert knowledge. Our basic theoretical premise has been enivronmental protection with an objective to preserve space as a value everywhere and in all its forms. The purpose of environmental protection is to encourage and direct such spatial development that provides a long-term basis for human health, well-being and quality of life as well as maintaining biotic diversity. This enables us to connect space with all its parts and features, sport recreation and tourism, thus achieving quality of life of local inhabitants, well-being of guests, protection of the natural environment, economic development, creation of new work places and income.

KEY WORDS: environmental protection, recreation, tourism, River Soča, landscape park.

obisk še sprejemljiv zanj, da pri tem zagotavlja tudi kakovostno turistično storitev.

Vodni in obvodni prostor v Zgornjem Posočju spada med krajine, ki so poleg gozdov ohranile veliko prvobitnosti, in je med najprivlačnejšimi območji za preživljanje prostega časa in rekreacijo. Je hrbtenica zasnove sistema športnorekreacijskih površin v naravnem okolju. Za turizem so zanimiva naravna 
prizorišča, saj v zadnjem času narašča povpraševanje po preživljanju prostega časa $\mathrm{v}$ naravi, kar je med drugim posledica čedalje večjega deleža mestnega prebivalstva (nasproti podeželju), višjega življenjskega standarda in boljše prometne dostopnosti. Čedalje večji turistični obisk v naravi je vplival na stanje naravnega okolja, posebno $\mathrm{v}$ gorskih občutljivih ekosistemih, prav tako pa tudi na socialno okolje. Turistična dejavnost, predvsem rekreacijska in tudi športna (Butler in dr., 1999), je v nasprotju $s$ hotelskimi kompleksi iskala nove možnosti in jih našla $\mathrm{v}$ aktivnem preživljanju prostega časa $\mathrm{v}$ ohranjeni naravi. Poleg tradicionalnejših dejavnosti (planinstvo in gorništvo, smučanje, kopanje) so se sprva posamično, potem pa tudi organizirano pojavile nove alternativne dejavnosti. Razvili so se gorsko kolesarjenje, jadralno padalstvo, helismučanje, na vodah pa kajakaštvo, raftanje, soteskanje, breznenje, hydrospeed ipd.

Šport in prostočasne dejavnosti v naravnem okolju v zadnjem času zelo ogrožajo naravno ohranjenost vodnega in obvodnega prostora. V naši državi še ne poznamo mehanizmov za omejevanje kapacitet in dovoljenega gibanja $v$ nekem času. Pri rabi reke Soče in drugih voda vsakdo uporablja vodni in obvodni prostor brez posebnih omejitev, podobno se dogaja s kopanjem v Triglavskih jezerih. Opredeliti bo treba:

- območja za športne in prostočasne površine $\mathrm{v}$ naravnem okolju,

- območja varstva vrednot, kjer bodo prostočasne aktivnosti prostorsko in časovno omejene (opredeliti je treba kritično mejo rabe naravne dobrine),

- območja za prostočasne aktivnosti s koncesijo.

Vodni in obvodni svet reke Soče je tisti del krajine, ki je ohranil veliko prvobitnosti in je obenem nosilec največje strukturne in biološke raznovrstnosti (internet 3; internet 4).

Voda je pomembna prvina naravnega in bivalnega okolja, je življenjsko okolje številnim organizmom, zato moramo $\mathrm{z}$ njo in vodnim ter obvodnim prostorom ravnati odgovorno in ob tem misliti tudi na prihodnje generacije.

Območje je ohranilo tradicionalno obliko slovenskega podeželja, zelo malo pa je bilo storjenega za planiranje in izrabo prostora, zato $\mathrm{v}$ članku predlagamo eno izmed možnih smernic za izboljšanje tega območja na področju varstva okolja, rekreacije in turizma, da bi obudili, ohranjali in negovali vse tiste značilnosti kulturne in zgodovinske dediščine, ki so ključne za prepoznavnost Zgornjega Posočja (internet 1 ; internet 2 ; internet 8 ; internet 10 ).

\section{Metode dela}

Metodologija temelji na interdisciplinarni povezavi ekspertnih spoznanj posameznih strok, npr. varstva okolja, kineziologije, psihologije, sociologije, prostorskega planiranja, ekonomije.

Namen raziskovalnega dela je oblikovanje ureditve rekreacijske rabe reke Soče in možnega prostorskega razvoja na primeru Zgornjega Posočja.

Opredelitve problemskih izhodišč temeljijo na poznavanju problematike obravnavanega prostora in okolja, terenskem delu, fotografiranju, skeniranju in kartiranju območja, zbranih statističnih podatkih, izdelanih študijah in drugem dostopnem gradivu.

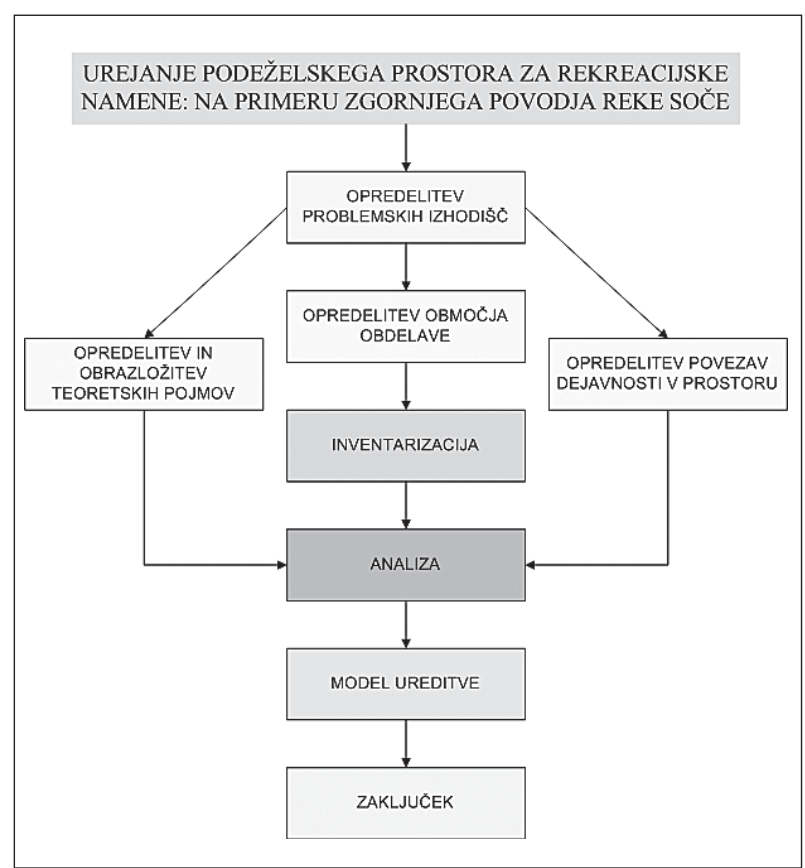

Slika 1: Prikaz metode dela.

\section{Območje predloga ureditve}

Največji pritiski turizma na okolje v Posočju so v poletnih mesecih na devetkilometrskem odseku reke Soče, od vstopnega kraja Log Čezsoški do izstopnega kraja Trnovo ob Soči, zato se v nadaljevanju s predlogom ureditve omejujemo na to območje (Golja, 2005).

V Zgornjem Posočju se čedalje bolj konfliktno srečujejo oblast (država in občine, med katerimi je premalo zanimanja za skupno reševanje problemov), domači in tuji podjetniki, ki tržijo reko Sočo legalno in nelegalno, in lokalno prebivalstvo, ki najbolj neposredno občuti neurejene razmere. 
V zadnjih nekaj letih se je rekreacija na reki in ob njej močno razmahnila. Za kajakaštvo in raftanje je najbolj obiskan del med Lepeno in Kobaridom, najbolj obremenjena dela med turistično sezono pa Log Čezsoški in Trnovo ob Soči. Povečan obisk negativno vpliva na okolje reke Soče. V zadnjih letih je Zgornje Posočje priča pospešenemu razvoju turizma, ki se premočno opira na reko in njene pritoke (Golja, 2005; Mlekuž, 1999).

\subsection{Načrtovanje in ureditev rekreacijske rabe na in ob vodi, izkušnje $\mathrm{v}$ tujini}

V drugih državah, zlasti $\mathrm{V}$ ZDA in drugih anglosaških deželah, se kompleksnosti urejanja rekreacijske rabe bistveno bolj zavedajo. Načrtovanje rekreacijskih dejavnosti, med katerimi je tudi rekreacija na in ob vodi, obravnavajo državni planski dokumenti (državni plani za rekreacijo na prostem kot sestavine vodarskih planov) (internet 6; internet 12).

Načrtovanje, ki izhaja iz stanja, potreb prebivalstva (anketni vprašalniki), prostorskih možnosti, vključevanja javnosti $v$ različne faze postopka, od zvezne ravni navzdol, poteka interdisciplinarno z vključevanjem različnih uradov, agencij in parkov (Brumil in dr., 1999). V Angliji sprejemajo za rekreacijo smernice strategije in politike, prav tako pa tudi lokalne (operativne) plane okoljskih agencij (internet 11).

Velik poudarek je namenjen dostopnosti voda in razpoložljivosti zemljišč za urejanje infrastrukture, ki je povezana z lastništvom. Razen zemljišč na območjih s statusom varovanja je večina zemljišč v različnih oblikah v zasebni lasti (internet 7). Uporaba zemljišč z opredeljenimi obveznostmi udeležencev je urejena z odškodninami oz. rentami.

Ureditev vodnorekreacijskih dejavnosti je v parkih drugih alpskih držav različna (Šolar, 2002). V Nemčiji so dejavnosti načeloma dovoljene, prepovedane in omejene pa na območjih s pomembno naravno dediščino. V narodnem parku Berchtesgaden so zakonsko prepovedane.

Francija je bila $\mathrm{v}$ preteklosti najbolj liberalna, a imajo zaradi preobremenjenosti naravnega okolja $\mathrm{Z}$ vodnimi športi $\mathrm{v}$ zadnjem času velike težave. $\mathrm{V}$ narodnih parkih so že vpeljali omejitve (internet 9). Kjer so vodni športi dovoljeni, so določene stalne vstopne in izstopne točke, urejena so varovališča.

Avstrija ureja vodne športe $\mathrm{z}$ deželnimi zakoni o varstvu narave (internet 5). Upoštevane so strokovne podlage naravovarstvenih ustanov. Mirne cone so izločene, zato tam športnorekreacijska raba ni do- voljena. V narodnem parku Hohe Tauern (internet 13) so športnorekreacijske dejavnosti na vodotokih prepovedane. Kjer je rekreacija dovoljena in infrastruktura urejena, je lastnikom zemljišč priznana letna odškodnina.

\subsection{Analiza stanja ožjega obravnavanega območja}

V zadnjih letih je Zgornje Posočje priča pospešenemu razvoju turizma, ki se premočno opira na reko in njene pritoke.

Nadzora nad posegi v prostor ni, kar je posledica neusklajenega delovanja sektorjev, ki v tem obdobju niso našli ustreznih sistemskih rešitev. Ob takšnem pomanjkanju državne in strokovne podpore so se ljudje samoorganizirali po lastnih močeh, zato so se nakopičili navidezno nerešljivi prostorski problemi (parkirni prostori, sanitarni prostori ipd.), kar je privedlo do neprimernih posegov za okolje (Golja 2005).

\subsubsection{Problem prostorske ureditve}

Rekreacijske dejavnosti na in ob vodi so skupina aktivnosti, ki pogojujejo čim bolj ohranjeno naravno okolje z visoko doživljajsko vrednostjo (Jeršič, 1999). Kljub temu pa tudi tako imenovane mehke dejavnosti zahtevajo za svoje delovanje prostorske ureditve, ki posredno in tudi neposredno posegajo na vodna in priobalna zemljišča, ki pa za obravnavano območje niso urejena:

- dovozne ceste,

- parkirne površine,

- sanitarni prostori,

- objekti za začasno (sezonsko) skladiščenje opreme,

- gostinski (začasni) objekti ali prostori za piknik,

- prostori za šotorjenje,

- pešpoti (stopnišča),

- vstopne in izstopne točke na vodnih zemljiščih,

- obrežni varovalni objekti,

- varovališča,

- privezi, pomoli.

Pri opravljanju dejavnosti je treba zagotavljati varnostne ukrepe, nadzor, čiščenje in stalen odvoz odpadkov ter praznjenje sanitarnih blokov.

\subsubsection{Vpliv dejavnosti}

Pri obravnavanju vplivov se je treba zavedati, da so gorski vodotoki izredno ranljivi. Večina njih kot tudi obravnavani odsek reke Soče so naravne vrednote, pomembne zaradi hidroloških, geomorfoloških, botaničnih in zooloških značilnosti (internet 10). 
Negativni vplivi zaradi različnih rekreacijskih in turističnih dejavnosti nastajajo predvsem zaradi (Pogačnik, 1992; Prosen, 1993):

- posegov v relief (ureditev parkirišč in poti, dostopnih in izstopnih točk, rampe za spuščanje in dviganje čolnov, žičnice, varovališča, brvi),

- posegov v vegetacijo (odstranitev dreves in grmičevja, uničevanje podrasti),

- posegov v živalski svet (ureditve varovanja za ljudi so lahko omejitve gibanja živali),

- posegov na vodotokih (spremembe prečnega prereza, ureditve in opremljanje - sidrišča, klini),

- vidne izpostavljenosti.

Izvajanje dejavnosti pa povzroča različne negativne vplive (Jeršič, 1999):

- motenj posesti,

- erozije in poškodb tal,

- hrupa (motorni promet, glasno komuniciranje uporabnikov),

- vožnje in ustavljanja vozil v naravnem okolju,

- motenj vodnih in obvodnih ekosistemov,

- divjih šotorišč in kurišč,

- motenj živalskih vrst $\mathrm{v}$ prej mirnih conah (vodne ptice, gnezdišča redkih in ogroženih vrst, drstišča rib, habitati vider),

- poškodb rastlinskih vrst (odstranjevanje ali obsekavanje nadzemnih delov, poškodbe podrasti; odnašanje mahov v strugah),

- vnašanja tujerodnih vrst oz. preštevilnih populacij določenih vrst zaradi komercialnega ribolova,

- onesnaženosti z odpadki in odplakami,

- konfliktov z drugimi dejavnostmi.

\subsubsection{Prometna obremenitev obravnavanega območja}

Direkcija Republike Slovenije za ceste ima na regionalni cesti Bovec-Kobarid v kraju Srpenica postavljeno napravo za avtomatsko štetje prometa. Iz dobljenih podatkov povprečnega letno-dnevnega prometa (Direkcija Republike Slovenije za ceste, 2007) se ne da določiti števila tranzitnega prometa, so pa rezultati $\mathrm{v}$ pomoč, da dobimo pregled, kolikšne so dnevna, mesečna in letna prometna obremenitev za leto.

Pregled povprečnega letno-dnevnega prometa za vsa vozila v obe smeri v poletni sezoni za leto 2007 , Srpenica, števno mesto 96 :

- povprečni letno-dnevni promet (PLDP) za poletno obdobje znaša 3020 vozil,

- največji mesečni promet, avgust, 108.445 vozil, povprečno 3498 vozil na dan.

$\mathrm{Z}$ veliko verjetnostjo in subjektivno oceno lahko predvidevamo, da gre v turistični sezoni čez to območje približno 150.000 motornih vozil.

\subsection{4 Športnorekreacijska plovba po reki Soči}

V letih 1996 in 1997 je potekal organiziran monitoring rekreacijske rabe reke Soče, ki ga je izvajalo podjetje Oikos, d. o. o. (Oikos, d. o. o., 1996, 1997), v programu PHARE (Phare, 1997). Monitoring je bil zaradi pomanjkanja finančnih sredstev organiziran le tri dni v največji turistični sezoni na delu Soče od dostopnega mesta Kluže in Zmuklica do Trnovega ob Soči.

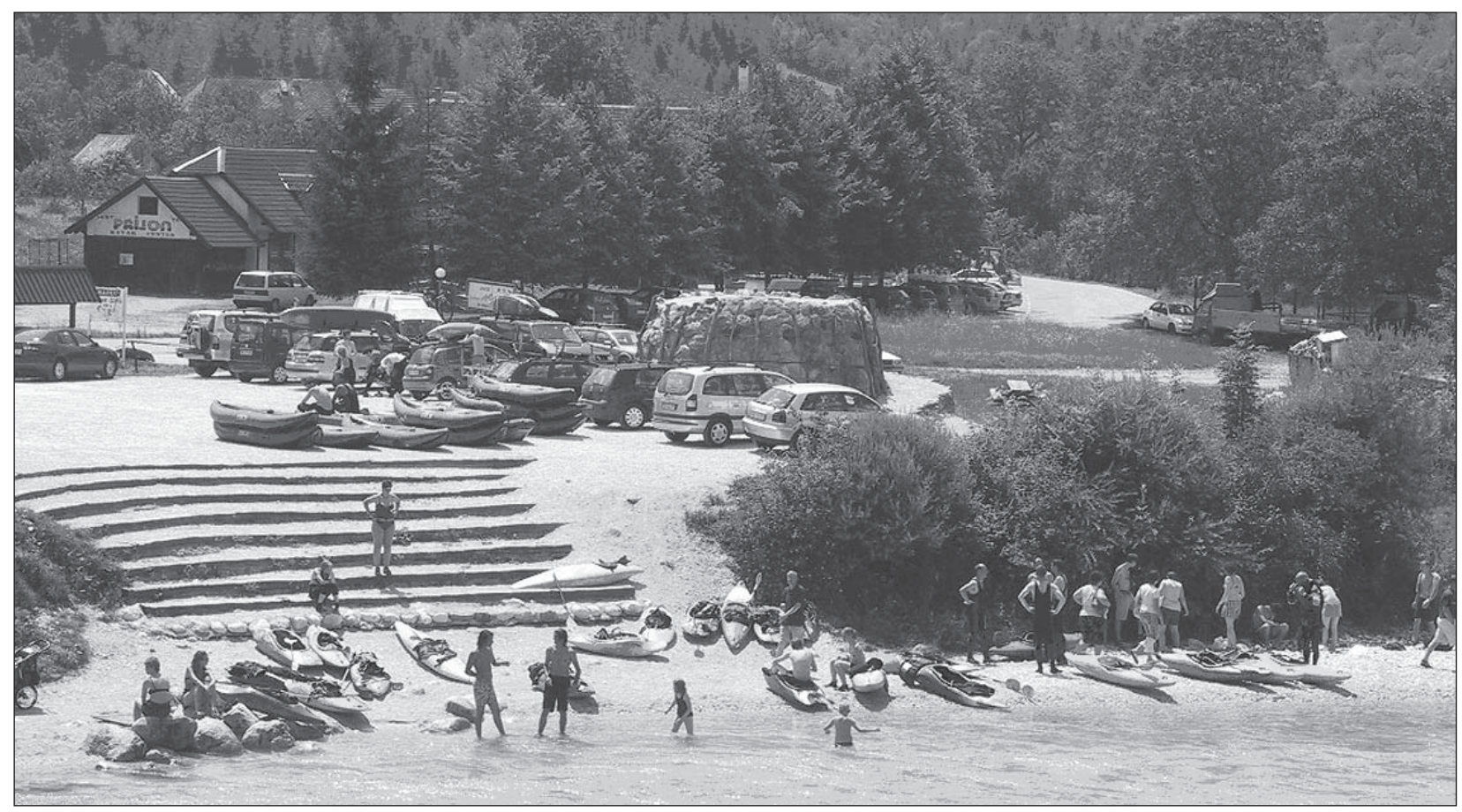

Slika 2: Čezsoča, 2004. (Foto: Aleš Golja) 
Leta 2003 in 2007 smo ponovili monitoring rekreacijske rabe reke Soče, ki je obsegal devet km dolg odsek reke Soče, od vstopnega kraja Log Čezsoški do izstopnega kraja Trnovo ob Soči. Ta del je najzanimivejši in v največji turistični sezoni najbolj obremenjen. Leta 2003 je izvedba monitoringa potekala dva dni v maju, štiri dni v juliju in dva dni v avgustu. Leta 2004 je potekala tri dni $v$ juliju, $v$ času potresa. Leta 2006 je izvedba monitoringa potekala en dan v juliju, leta 2007 pa en dan v juniju, 12 dni v juliju in dva dni v avgustu (Golja, 2005).

\subsubsection{Analiza podatkov spremljanja stanja}

Dobljene podatke smo primerjali s podatki monitoringa iz let 1996 in 1997. Ugotovili smo, da je največje povečanje pri čolnih dvosedih (outsider) in kajakih, pri raftanju pa je stanje rahlo poraslo. Kar zadeva število ljudi, ki se spustijo po reki Soči, v določenih dnevih največje turistične sezone preseže 900 oseb na dan (julij 2003), 800 oseb na dan (julij 2004), 900 oseb na dan (julij 2006) in 1100 oseb na dan (julij 2007).

Glede na dobljene podatke lahko z veliko verjetnostjo trdimo, da je reka Soča preobremenjena ob koncih tedna v juliju in prva dva konca tedna v avgustu. Prevladujejo predvsem »vikend « gostje, ki so večinoma nastanjeni po kampih in prihajajo iz vzhodnoevropskih držav (Madžarska, Češka, Slovaška) in sosednje Italije. Tedenskih gostov je manj in prihajajo iz bolj oddaljenih zahodnoevropskih držav (Nemčija, Nizozemska). Po podatkih turističnega informacijskega

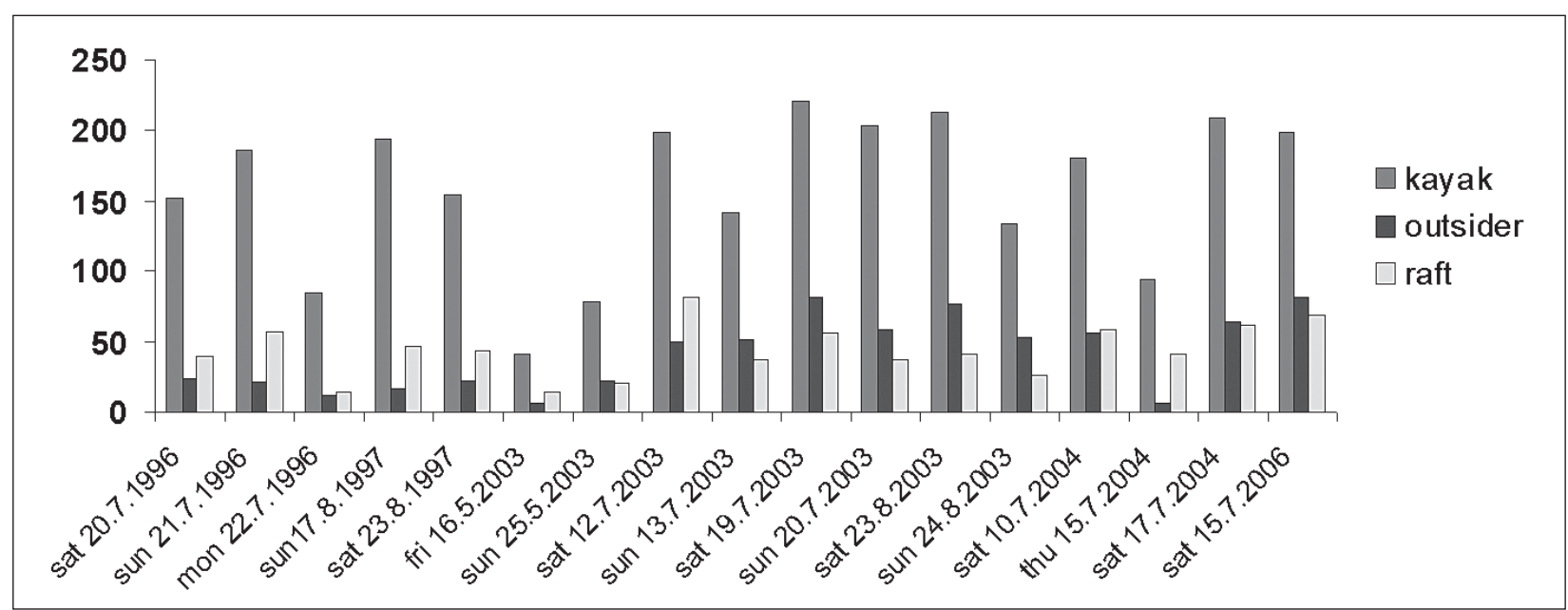

Slika 3: Število plovil po posameznih dnevih v letih 1996, 1997, 2003, 2004, 2006.

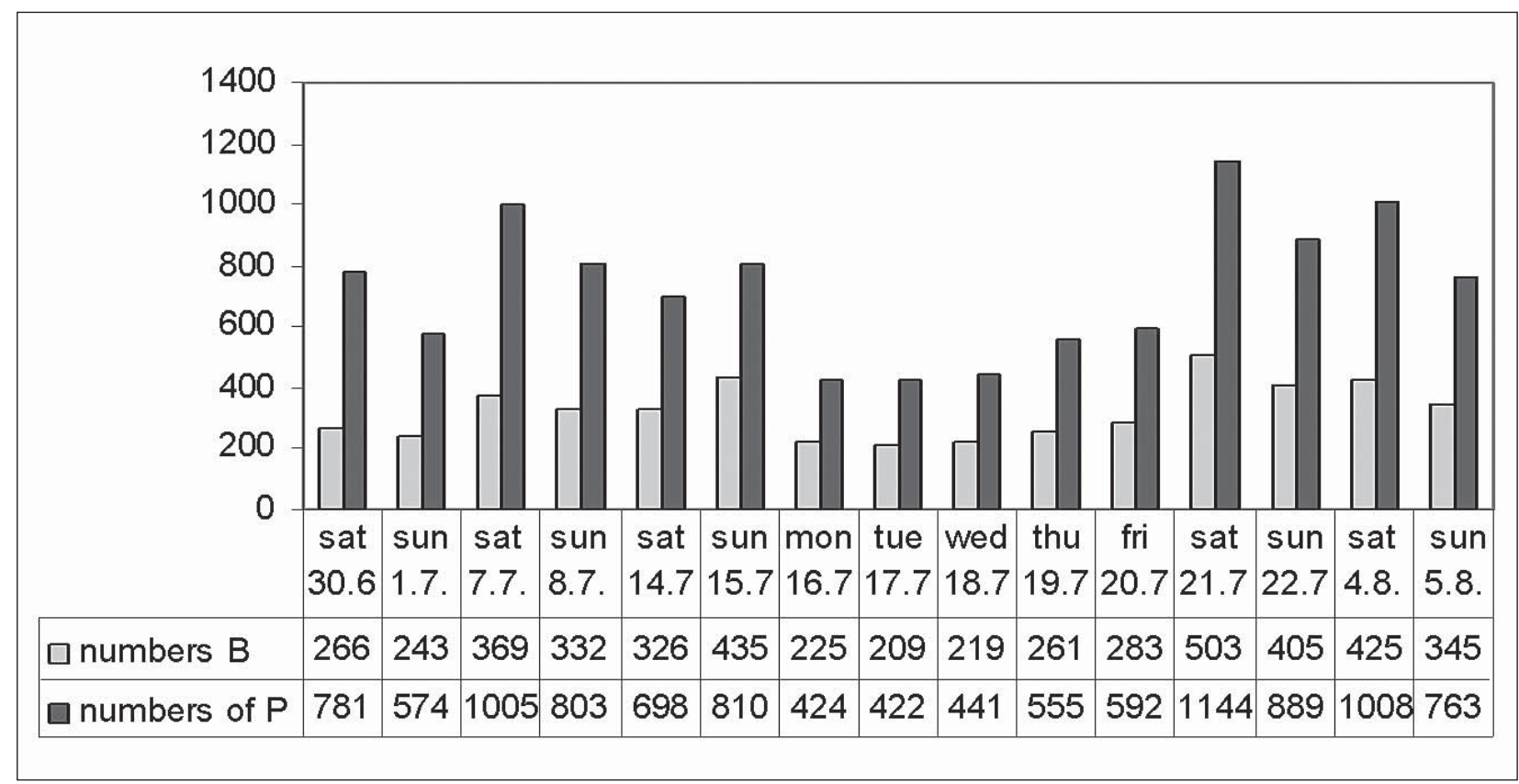

Slika 4: Število plovil in število oseb po posameznih dnevih med 30. 6. 2007 in 5. 8. 2007. 
centra je med letom 2004 in letom 2007 reko Sočo uradno tržilo več kot 24 podjetij.

\subsubsection{Tržna analiza}

Trajnostni razvoj turističnih območij temelji med drugim na izboljšanju izkoristka turističnih zmogljivosti. Tako se izognemo potencialnim okoljskim problemom, ki nastanejo ob gradnji novih turističnih objektov.

Povprečno število prenočitev gostov od leta 2000 do leta 2006 je bilo približno 171.000 na leto (Statistični urad Republike Slovenije, 2007), povprečna dolžina bivanja gostov pa približno 2,3 dneva na leto. Iz dobljenih rezultatov lahko ugotovimo, da je zasedenost turističnih zmogljivosti v Zgornjem Posočju manj kot 15 odstotkov na letni ravni.

Po neuradnih podatkih turistične zveze Tolmin je v Zgornjem Posočju najmanj 25 odstotkov neprijavljenih prenočitev.

V Zgornjem Posočju so občine predložile več načrtov ureditve rekreacije ob reki Soči (Občinski svet Bovec, 2000; Občina Tolmin, 2001; Občina Kobarid, 2002). Načrtovale so uvedbo parkirnine na dostopnih krajih, uvedbo dovolilnic za spuste po reki itd. Edina občina, ki je sprejela in izvajala občinski odlok o plačevanju pristojbine za uporabo dostopnih krajev do reke Soče, je bil Bovec.

\section{Ključni problemi in razvojne ovire}

Zdajšnje stanje kaže na nezadovoljivo stopnjo razvoja turizma in rekreacije glede na izreden turističnorekreacijski potencial območja $\mathrm{z}$ naslednjih vidikov (Golja, 2005):

- neusklajenost občinskih politik in državnih zakonov,

- razdrobljenost turistične ponudbe,

- neustrezno razmerje med ceno in kakovostjo turističnih storitev in ponudbe,

- slaba zasedenost turističnih zmogljivosti vse leto,

- stihijski (neurejen) turizem, ki omogoča vdiranje tujih podjetnikov, katerih cilj je hiter zaslužek ne glede na dolgoročne učinke (freeriderski odnos),

- nenadzorovan vdor tujega kapitala,

- beg možganov iz prostora,

- slabi poslovni rezultati turističnega gospodarstva,

- pomanjkanje ustreznih človeških virov (strokovnega kadra $\mathrm{v}$ turizmu in slaba usposobljenost zdajšnjega),

- množični turizem, ki zlasti ob sezonskih konicah preobremenjuje okolje,

- tragedija skupnega - tragedy of common (maksimiziranje individualnih koristi na račun javnih dobrin),

- sezonskost povpraševanja,

- premajhna usposobljenost lokalnih ponudnikov za tekmovanje na odprtem trgu.

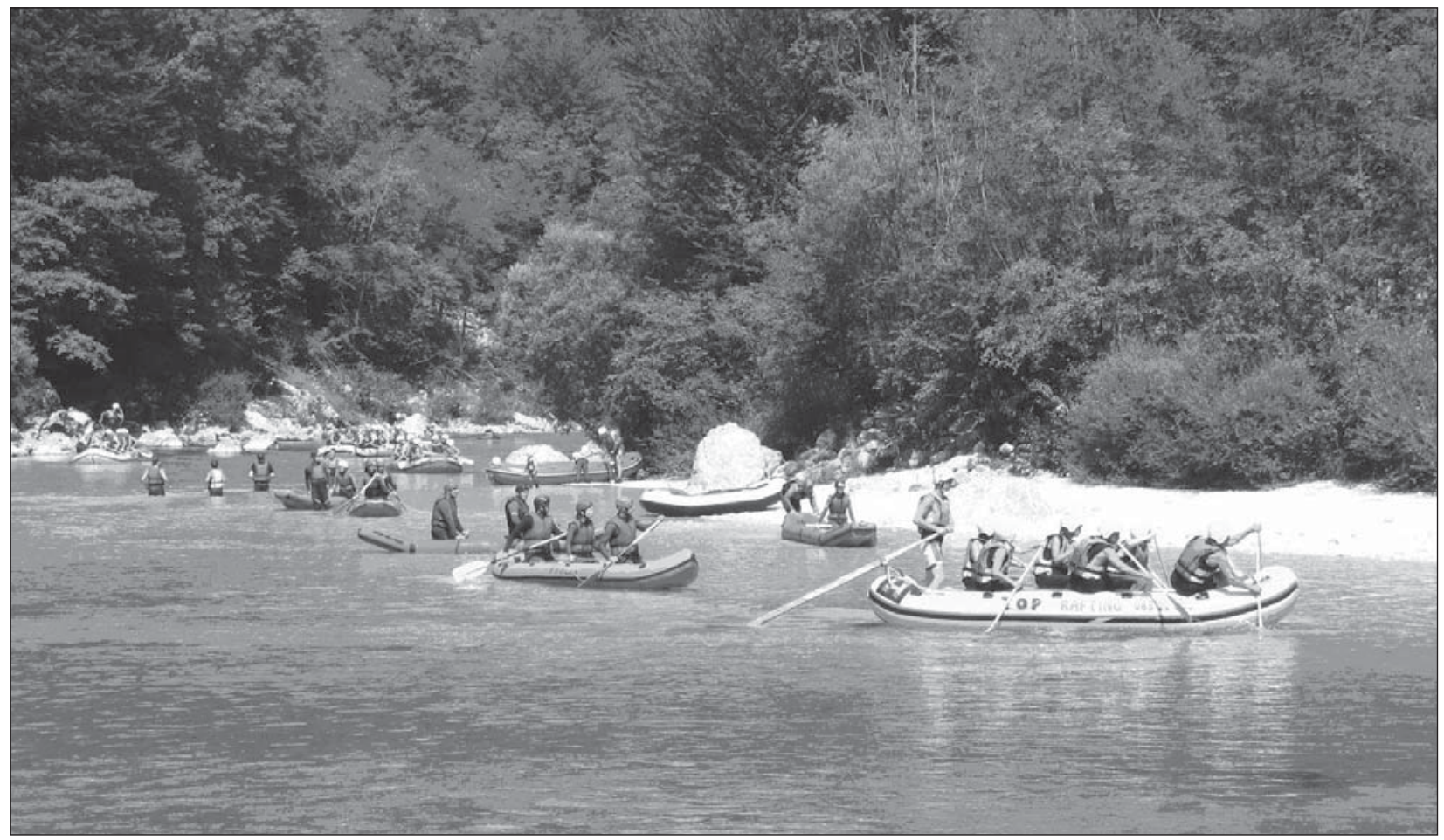

Slika 5: Monitoring Srpenica 2, 2007. (Foto: Aleš Golja) 
Posegi v prostor so bolj ali manj trajni, vplivi opravljanja dejavnosti pa začasni, vezani na sezono od aprila do novembra. Največje obremenitve so ob koncu tedna v visoki poletni sezoni, kar je čas nizkih pretokov, hkrati pa se časovno ujema tudi s sicer najbolj množičnim obiskom (izletniški turizem, druge rekreacijske dejavnosti).

\section{Koncept predloga}

Ena od rešitev, ki bi ustrezno pokrila vse zahteve reke Soče v Zgornjem Posočju, izkoristila njene potenciale za rekreacijo, turizem in hkrati smiselno vključila lokalno prebivalstvo, je ustanovitev krajinskega parka Zgornje Posočje s sektorjem za urejanje in trženje plovbe na reki Soči (Golja, 2005). Predlog za ustanovitev krajinskega parka bi podal iniciativni odbor Zgornjega Posočja, v katerega bi bile vključene občine Tolmin, Kobarid, Bovec $z$ vsemi lokalnimi turističnimi organizacijami, Turistično zvezo Zgornjega Posočja in Posoškim razvojnim centrom.

Sektor s poudarjeno funkcijo urejanja in trženja plovbe po reki Soči za komercialne namene v krajinskem parku Zgornje Posočje bi skrbel za planiranje zmogljivosti in upravljanje dejavnosti, povezanih s plovbo na Soči; ribolov, obrtno ali industrijsko izrabo ter drugo pa še naprej ureja veljavna zakonodaja.

Krajinski park Zgornjega Posočja s sektorjem za urejanje in trženje plovbe na reki Soči bi pomenil velik potencial za trajnostni razvoj in ohranjanje naravovarstvene vrednosti okolja obravnavanega območja, saj so vse dejavnosti sektorja za urejanje in trženje plovbe na reki Soči povezane $\mathrm{z}$ delovanjem krajinskega parka.

Krajinski park kot institucija omogoča sektorju, da kakovostno opravlja svoje naloge, spremlja dejavnosti in dogajanje na reki Soči, pri čemer postaja park urejen, povečata se njegova vrednost in prihodek. Ustvarjeni prihodek se nameni za oživljanje in ohranjanje naravnega okolja krajinskega parka (za stroške investicij, vzdrževanja, nadzora in administracije).

Krajinski park Zgornje Posočje (v nadaljevanju KP) s sektorjem za urejanje in trženje plovbe na reki Soči (v nadaljevanju SUTP) bi obsegal vse tri občine

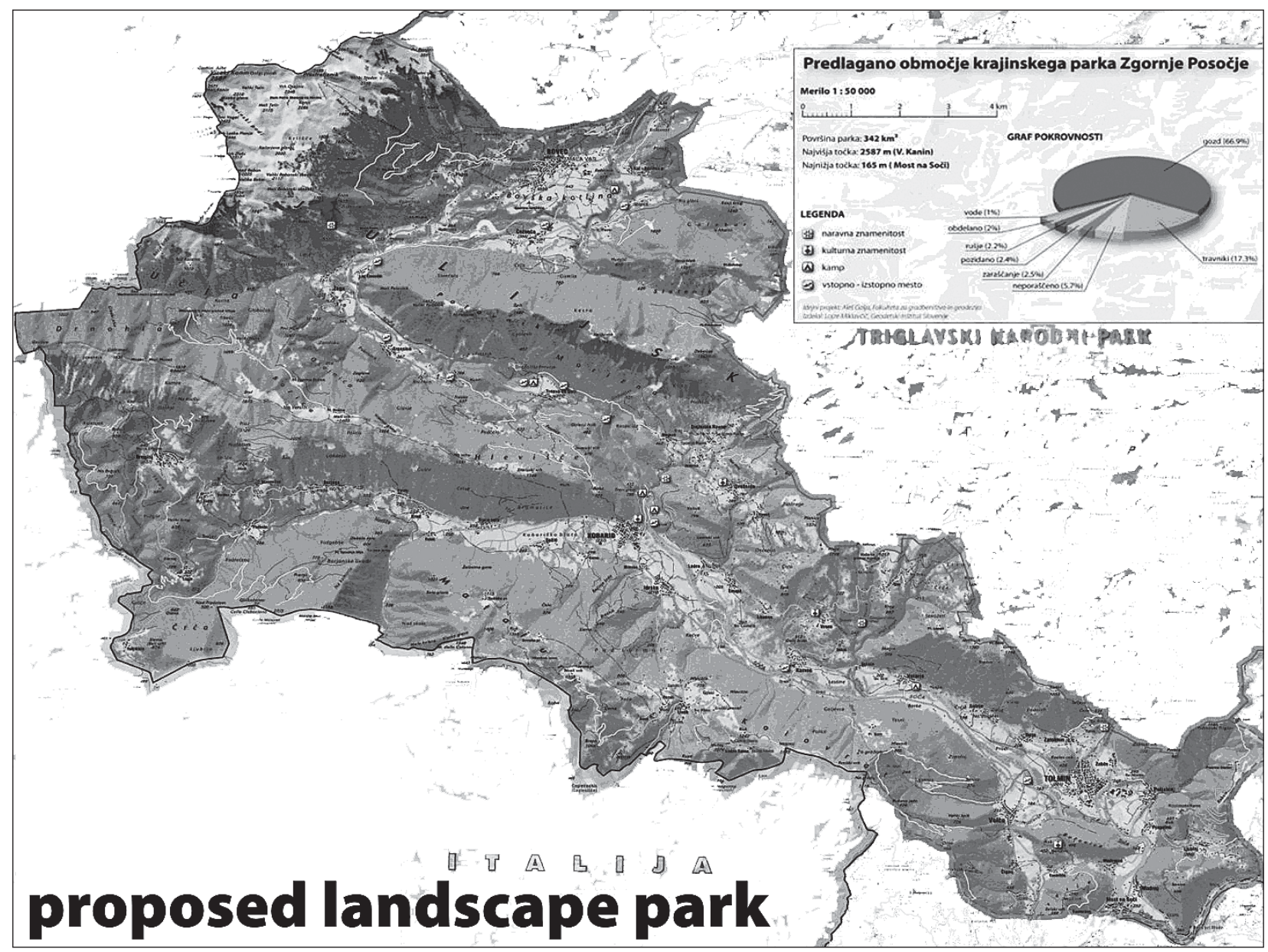

Slika 6: Predlagano območje krajinskega parka Zgornje Posočje; velikost 342 km², najvišja točka 2587 m, najnižja točka 165 m. 
Zgornjega Posočja brez zavarovanega območja TNP do Mosta na Soči (meja predlaganega krajinskega parka Trnovski gozd po predlogu Natura 2000).

\subsection{Ocena prilivov finančnih sredstev KP in SUTP}

Po organizacijski strukturi sta mogoči alternativni rešitvi, kar se navezuje na oceno prilivov finančnih sredstev KP in SUTP:

- Predlog alternativne rešitve A: realna različica.

- Predlog alternativne rešitve B: optimistična različica.

V obeh predlogih se KP obravnava kot stroškovno mesto odgovornosti, katerega namen je ohranjanje naravnega okolja in splošno dobro družbe. Sredstva se namenijo za vzdrževanje in investiranje $\mathrm{V}$ KP za ureditev celotne infrastrukture KP (ureditev parkirišč, dovoznih poti, komunalne infrastrukture - sanitarnih prostorov, objektov za skladiščenje opreme, prostorov za piknik in kampiranje, pešpoti, vstopnih in izstopnih točk ob vodi, varovališča in ureditev privezov ter pomolov in drugih potrebnih ureditev), izobraževanje kadrov, vključevanje lokalnega prebivalstva s subvencioniranjem ekstenzivnega kmetijstva, obnovo objektov naravne in kulturne dediščine, nepredvidene sanacije ali druga nepredvidena potrebna dela ter razvojne študije.

SUTP bi skrbel za pravila in navodila za rabo reke Soče, registracijo plovil, podeljeval dovolilnice za komercialno izvajanje rekreacijske dejavnosti na reki in odnose $\mathrm{z}$ izvajalci teh dejavnosti.

Razlika med predlogoma je ta, da realna različica išče možnosti financiranja predvsem iz državnega proračuna in drugih virov, optimistična različica pa išče možnosti $\mathrm{v}$ lastnih sredstvih $\mathrm{z}$ zaračunavanjem okoljevarstvene takse za vstop motornega vozila v predlagano varovano območje, pri čemer mora plačati koncesijsko takso državi.

\subsubsection{Predlog alternativne rešitve A: Realna različica}

Možni viri financiranja:

- državni proračun: Ministrstvo za okolje in prostor; Ministrstvo za ekonomske odnose in razvoj; Ministrstvo za gospodarske dejavnosti; Ministrstvo za kmetijstvo, gozdarstvo in prehrano; Ministrstvo za kulturo; Ministrstvo za šolstvo in šport; Ministrstvo za visoko šolstvo in znanost; pridobivanje projektov na javnih razpisih,

- Evropska unija: finančna pomoč iz strukturnih in kohezijskih skladov Evropske unije,
- donacije in sponzorstvo,

- lastni viri znotraj KP (\% TT, dovolilnice za izvajanje dejavnosti na reki in registracije polovil).

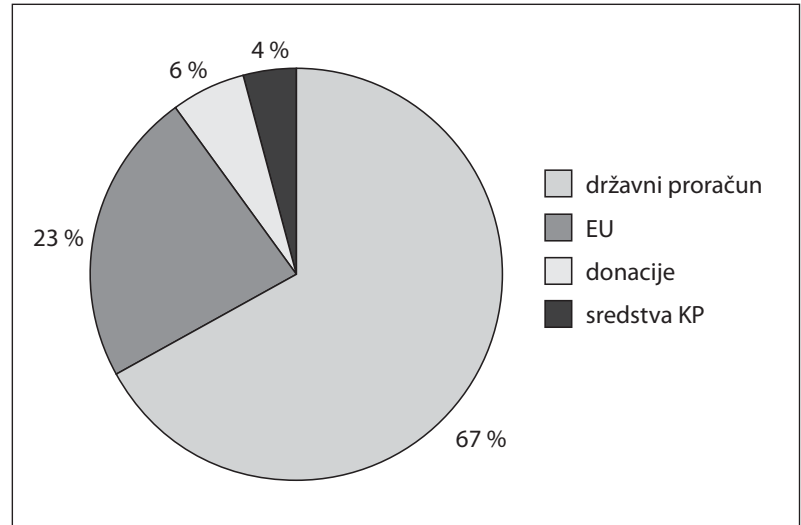

Slika 7: Struktura prihodkov KP (A)

\subsubsection{Predlog alternativne rešitve B: Optimistična različica}

Možni vir financiranja:

- lastni viri znotraj KP (okoljevarstvena taksa za motorna vozila, ki vstopajo v območje KP, delež TT, dovolilnice za izvajanje dejavnosti na reki in registracije plovil).

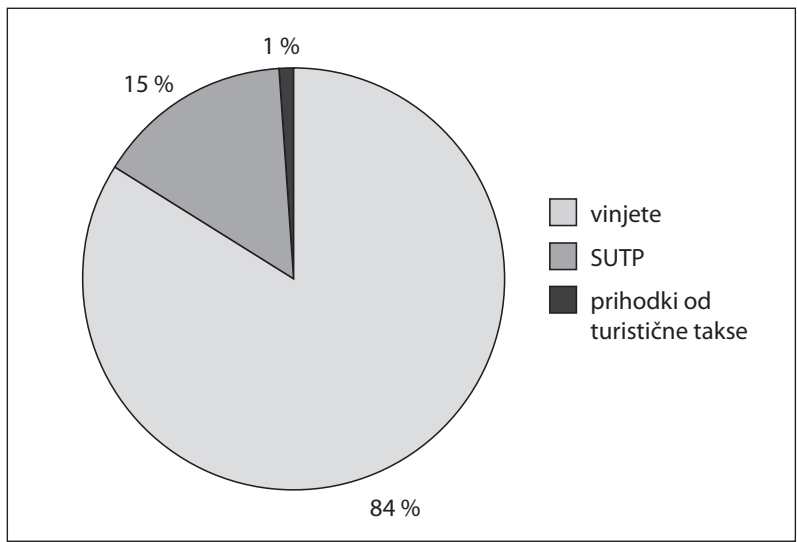

Slika 8: Struktura prihodkov KP (B).

\subsubsection{Primerjava različice A: realna rešitev in različice} B: optimistična rešitev

Iz različnih hipotetičnih izračunov lahko ugotovimo, da je dolgoročno gledano za vse akterje predlagane ureditve različica B ugodnejša. Po njej nima država kot upravljavka nikakršnih stroškov vodenja parka, zaradi pravice podeljevanja koncesij in pridobivanja sredstev iz naslova koncesijske pogodbe lahko pričakuje redni priliv. 
V nasprotju s tem pa različica A prinaša državi velik začetni finančni vložek, dolgoročno s takim poslovanjem ne more pričakovati rednih prilivov.

Govoriti o vsebini ter finančni vrednosti in dinamiki investicijskih projektih je v tej fazi nemogoče, zagotovo pa jih je treba prvotno usmeriti v posodobitev primarne infrastrukture. Kolikšna je realna vrednost deleža, namenjenega posamezni investiciji krajinskega parka, ni mogoče izračunati, saj je to odvisno od ocene trenutnega stanja in potreb, ki ga opravi strokovno vodstvo KP.

V začetnem obdobju delovanja KP je primarno vodilo usmeriti lastna sredstva $\mathrm{v}$ razvojne projekte, ki bodo pridobili vire sofinanciranja od drugih financerjev.

\section{Sklep}

Z analizo dejanskega stanja obravnavanega območja lahko ugotovimo, da je bil dosedanji turistični razvoj Zgornjega Posočja nenačrten, kar je povzročilo onesnaženje okolja, konflikte (spore, nesporazume) med različnimi uporabniki reke, padec kakovosti turistične ponudbe, sivo ekonomijo in z njo povezane nesreče s smrtnimi izidi, ki so posledica nepoznavanja reke in njenih trenutnih razmer ob različnem vodostaju.

Analize podatkov kažejo tudi, da ne moremo govoriti o množični rekreaciji in turizmu obravnavanega območja, lahko pa povzamemo nekaj ugotovitev in poudarimo določene probleme:

- Rezultati zasedenosti prenočitvenih zmogljivosti regije Zgornjega Posočja (manj kot 15 odstotkov) (Statistični urad Republike Slovenije, 2007) in rezultati prometne obremenitve območja (Direkcija Republike Slovenije za ceste, 2007) (približno 150.000 motornih vozil od maja do septembra) so pokazali največjo koncentracijo povečanega obiska turistov julija in avgusta.

- Monitoring obravnavanega devetkilometrskega odseka reke Soče je pokazal povečan plovni promet v posameznih koncih tedna (približno 900 plovil in 1900 oseb na konec tedna) julija in avgusta.

- Parkirni prostori na vstopnih in izstopnih točkah glede na več obiskovalcev $\mathrm{v}$ turistični sezoni ne zagotavljajo primerne komunalne infrastrukture, dovolj parkirnih prostorov za motorna vozila.

- Vstopne in izstopne poti za uporabnike reke Soče so ponekod delno urejene in na nekaterih delih nevarne.

- Nesreče, ki so se dogajale, so bile posledica neprimerne opreme in nepoznavanja značilnosti in nevarnosti reke, ki jih pri različnih vodostajih skriva. Posamezne agencije s takšnim izvajanjem športnih aktivnosti ogrožajo varnost uporabnikov.

- Ni postavljenih pravil, kaj je varna in primerna oprema, kdo in pod kakšnimi pogoji lahko opravlja tovrstno gospodarsko dejavnost in ali so kakšne okoljevarstvene posebnosti na sami reki (pravila vedenja v obravnavanem naravnem okolju - kodeks etike) itd.

- Razdeljenost Zgornjega Posočja med tri lokalne skupnosti je otežila reševanje omenjenih težav, saj delno reševanje $\mathrm{z}$ vidika varstva okolja in konflikta interesov posameznih dejavnikov ni primerno.

- Na območju so v veljavi različni občinski odloki (Občinski svet Bovec, 2000; Občina Tolmin, 2001; Občina Kobarid, 2002) lokalnih skupnosti o rabi in varovanju dostopnih točk za športno plovbo ob reki Soči, ki so med seboj neusklajeni. Npr. uporabnik reke, ki vstopa v občini Bovec, je deležen pravil njihove lokalne skupnosti, ki zaračunava urejanje dostopa do reke, izstopa pa $\mathrm{v}$ občini Kobarid, ki opozarja uporabnike, da je izvajanje dejavnosti na lastno odgovornost.

Z opredelitvijo problemov, analize prostora in razmer smo spoznali, da bi bila za to območje ustrezna ustanovitev krajinskega parka Zgornje Posočje in sektorja za urejanje in trženje plovbe na reki Soči, ki bi pomenil celostno reševanje omenjene problematike.

Tako zastavljen koncept KP in SUTP ima več prednosti:

- usmeritev sredstev v reševanje problemov enega območja, kar povečuje možnost rešitve,

- dolgoročna stabilnost krajinskega parka in sektorja za urejanje in trženje plovbe, ki je nujno potrebna za dosego trajnostnega razvoja Zgornjega Posočja,

- fleksibilnost, ki omogoča najprimernejšo strukturo krajinskega parka in sektorja za urejanje in trženje plovbe za reševanje (ne)pričakovanih problemov v prihodnosti,

- interakcija ustvarjalskega sodelovanja krajinskega parka in sektorja dviguje urejenost in vrednost območja ter zaslužek in kapitalsko stabilnost območja,

- intenzivno vključevanje lokalnega prebivalstva $\mathrm{v}$ sistem,

- zaupanje lokalnega prebivalstva kot temelj uspešnega delovanja KP.

Preverili smo dve različici finančno-organizacijske strukture, realno in optimistično. Pri prvi je država (Republika Slovenija) ustanoviteljica in upraviteljica 
parka, pri drugi pa je država ustanoviteljica parka, za upravljanje pa podeli koncesijo. S primerjavo obeh smo ugotovili, da je za vse akterje ugodnejša optimistična, kar bi imelo predvsem pozitivne socialne učinke: povečani dohodki in zaposlenost, dvig življenjske ravni lokalnega prebivalstva ter ustvarjanje priložnosti za razvoj regije.

Tako bi bil poleg finančnega krogotoka, sistema varstva okolja in ohranjanja narave ustvarjen tudi korekten tristranski odnos med lokalnimi prebivalci, turisti in ponudniki turistične športnorekreacijske ponudbe, kar je temeljni pogoj za izboljšanje mikrosocialne klime prostora in trajnostno urejanje podeželskega prostora.

Mag. Aleš Golja, prof. šport. vzg.

Univerza $\vee$ Ljubljani, Fakulteta za gradbeništvo in geodezijo

E-pošta: ales.golja@ fgg.uni-lj.si

Dr. Mitja Brilly, univ. dipl. inž. grad., redni profesor

Univerza $\vee$ Ljubljani, Fakulteta za gradbeništvo in geodezijo

E-pošta: mitja.brilly@ fgg.uni-lj.si

\section{Viri in literatura}

Burmil, S., Daniel T. C., in Hetherington, J. D. (1999) Human values and perceptions of water in arid landscapes. Landscape and Urban planning, 44, str. 99-109.

Butler, R., Hall, M. C., Jenkins, J. (1999) Tourism in recreation in rural areas. New York, John Willey\&Sons.

Direkcija Republike Slovenije za ceste (2007) Avtomatsko štetje prometa 2007 (obdobje januar-september). Ljubljana.

Golja, A. (2005) Varstvo okolja in možnosti rabe reke Soče za rekreacijske namene. Magistrsko delo. Ljubljana, Univerza v Ljubljani, Fakulteta za gradbeništvo in geodezijo.

Internet 1: http://www.natura2000.gov.si/ (sneto 10. 2. 2002)

Internet 2: http://www.dolina-soce.com/ (sneto 11. 3. 2003).

Internet 3: http://www.pososki-rc.si/ (sneto 12. 3. 2003).
Internet 4: http://www.rra-sp.si/ (sneto 10. 2. 2002).

Internet 5: http://www.wildalpen.at/ (sneto 12. 3. 2003).

Internet 6: http://www.wildwaterrafting.com/southeastmap.html (sneto 15.2 .2003$)$.

Internet 7: http://www.riversaccess.org/index.htm (sneto 15. 3. 2003).

Internet 8: http://zakonodaja.gov.si/ (sneto 14. 2. 2002).

Internet 9: http://www.bcu.org.uk/ (sneto 17. 3. 2003).

Internet 10: http://www.zrsvn.si/slo/ng/ng_soca.asp (sneto 10. 10. 2001).

Internet 11: http://www.defra.gov.uk/wildlife-countryside/ (sneto 20. 3. 2003).

Internet 12: www.water.utah.gov/planning/ (sneto 1. 4. 2004).

Internet 13: www. hohetauern.at (sneto 25. 3. 2003).

Jeršič, M. (1999) Prostorsko planiranje rekreacije na prostem. Ljubljana, Ministrstvo za okolje in prostor, Urad Republike Slovenije za prostorsko planiranje.

Mlekuž, Ž. A. (1999) Podjetništvo v naravnih parkih: primer doline Koritnice $\vee$ TNP. Magistrsko delo. Ljubljana, Univerza $\vee$ Ljubljani, Ekonomska fakulteta.

Občina Kobarid (2002) Odlok o ureditvi plovbe v občine Kobarid. Kobarid.

Občina Tolmin (2001) Odlok o ureditvi plovbe v občini Tolmin. Tolmin.

Občinski svet občine Bovec (2000) Odlok o rabi in varovanju dostopnih mest za športno plovbo ob reki Soči. Bovec.

Oikos, d. o. o., Svetovanje za okolje (1996) Monitoring reke Soče. Domžale.

Oikos, d. o. o., Svetovanje za okolje (1997) Monitoring reke Soče. Domžale.

Phare (1997) Managment Plan for Recreational use of the Upper Soča river. European Commission Directorate General DG IA/B3.

Pogačnik, A. (1992) Urejanje prostora in varstvo okolja. Univerzitetni učbenik. Ljubljana, Mladinska knjiga.

Prosen, A. (1993) Sonaravno urejanje podeželskega prostora. Ljubljana. Univerza v Ljubljani, Fakulteta za arhitekturo, gradbeništvo in geodezijo, Katedra za prostorsko planiranje.

Statistični urad Republike Slovenije (2007) Statistični letopis 2007. Ljubljana.

Šolar, M. (2002) Načela usklajevanja rekreacijske rabe v zavarovanem območju na primeru Triglavskega narodnega parka. Magistrsko delo. Ljubljana, Univerza v Ljubljani, Biotehniška fakulteta. 